\title{
Process-Based Indicators for Timely Identification of Apricot Frost Disaster on the Warm Temperate Zone, China
}

\section{Yang Jianying}

China Academy of Meteorological Sciences

Zhiguo Huo ( $\nabla$ huozhiguo_cma@126.com )

China Academy of Meteorological Sciences

\section{Peijuan Wang}

China Academy of Meteorological Sciences

Wu Dingrong

China Academy of Meteorological Sciences

\section{Yuping Ma}

China Academy of Meteorological Sciences

\section{Research Article}

Keywords: Apricot, Frost process, Identification indicator, Monitoring and warning

Posted Date: March 15th, 2021

DOI: https://doi.org/10.21203/rs.3.rs-268838/v1

License: (c) (1) This work is licensed under a Creative Commons Attribution 4.0 International License. Read Full License 


\title{
Process-based indicators for timely identification of apricot frost disaster on the warm temperate zone, China
}

\author{
Jianying Yang ${ }^{\mathrm{a}}$, Zhiguo $\mathrm{Huo}^{\mathrm{a}, \mathrm{b}}$ *,Peijuan Wang ${ }^{\mathrm{a}}$, Dingrong $\mathrm{Wu}^{\mathrm{a}}$, Yuping $\mathrm{Ma}^{\mathrm{a}}$ \\ 1. State Key Laboratory of Severe Weather (LASW), Chinese Academy of Meteorological Sciences, Beijing 100081, China; \\ 2.Collaborative Innovation Center of Forecast and Evaluation of Meteorological, Nanjing University of Information Science \& \\ Technology, Nanjing 210044, China
}

\section{Abstract}

Frequent occurrences of extreme cold weather processes create severe agricultural/forest frost events, even given the background of global warming. In the warm temperate zone of China, which is the largest planting area for fresh apricot, late spring frost disaster has become one of the major meteorological hazards during flowering. To prevent cold weather-induced apricot frost events and reduce potential losses in related fruit economic value, it is vital to establish a meteorological indicator for timely and accurate identification of cold weather process-based apricot frost events, to provide support for timely apricot frost monitoring and warning in late spring. In this study, daily minimax temperature $\left(T_{\min }\right)$ and apricot frost disaster data during flowering were combined to establish meteorological identification indicators of apricot frost based on cold weather processes.

A process-based apricot frost model $f\left(D, T_{\text {cum }}\right)$ was firstly constructed, and characteristics of $T_{\text {cum }}$ (accumulated harmful temperature) were explored under different $D$ (duration days) based on the representation of historical apricot frost processes. Thresholds for the $T_{\text {cum }}$ for apricot frost in $1,2,3,4$ and more than 5 days of apricot frost process were determined as $-1.51,-2.92,-4.39,-5.84$

* Corresponding author at: No. 46, Zhongguancun South Street, Haidian District, Beijing 100081, PR China. Tel.: +86 1058993238 ; 
and $-7.31{ }^{\circ} \mathrm{C}$, respectively. Validation results by reserved independent disaster samples were generally consistent with the historical records of apricot frost disasters, with $89.00 \%$ accuracy for indicator-based identification results. Typical process tracking of the proposed identification indicator to an apricot frost event that occurred in North Hebei during April 3-9, 2018 revealed that the indicator-based identification result basically coincides with the historical disaster record and can reflect more detailed information about the apricot frost process.

Key words: Apricot; Frost process; Identification indicator: Monitoring and warning

\section{Introduction}

Frost, as a temperature-related meteorological disaster, has been recognized as a major threat to the normal growth and production of agriculture and forest productivity through freeze damage (Vitasse, et al., 2018). As public generally believe that climate change is a scientific conclusion, a decrease in the frequency and intensity of frost events has been speculated with global warming. Paradoxically, as temperatures increase in early spring, perennial crops such as fruit trees gradually become increasingly vulnerable to cold temperatures, because of climate fluctuation that has led to considerable phenological shifts, such as advancing the date of flowering, and accelerating vegetative development, leading to the advancement of frost-sensitive stages due to a warmer winter and spring (Shimono, 2011; Saeidi et al., 2012; Chen et al., 2014; Wang et al., 2018). Frost disaster is widely reported in North American ecosystems (Gu et al., 2008; Augspurger, 2013) and forest and fruit trees in Europe (Yann et al., 2018). Timely monitoring of the occurrence of frost events is of considerable importance for adopting targeted measurements to reduce economic and 
production losses.

(1)
economic plantings (e.g., beech, apple, coffee and tea) (Susan et al., 2018; Antonio et al., 2019; László et al., 2019) have been shown to be vulnerable to frost, with different performance characteristics and mechanisms in response to frost. For example, serious frost caused by an extreme cold event has been witnessed after an earlier growing season onset, resulting in considerable loss of fruit tree yield and quality (Frederiks et al., 2015; Crimp et al., 2016). Additionally, cold tolerance varies between species. When the low temperature weather continues and frost stress increase, plants are injured irreparably, with destruction in fruit yield and quality, that is, a fruit tree frost event. To trigger a fruit tree frost event, two fundamental factors must be linked: the first is the cold weather event, including the starting/ending time, duration, degrees of cold, etc. The second is the plants' characteristics against cold, which always differs based upon the target fruit tree species and its phenological phase (Yang et al., 2016; Yang et al., 2020).

To explore the cold weather conditions that cause a frost event, studies on the frost effect on fruit trees have been primarily focused on environment-controlled experiments (Hatice et al., 2019;), designing specific experiments by controlling cold environment to examine the mechanisms of frost effect and the relationships with yield and quality factors. Through controlled experiments, the impacts of low temperatures on crop or fruit trees can be directly observed and detected, following the strategy of changing one element while others are stably maintained. 
Largely, attention been focused on the spatiotemporal patterns of meteorological frost and their influences on crops (Xiao et al., 2018) in regional assessment. Long series of historical meteorological and yield data have generally been combined to explore the negative impact of frost on crop and fruit trees, affiliating its spatiotemporal distribution and risk changes. For example, Xiao et al. (2018) analyzed frost risk from a meteorological perspective based on the relationship between meteorological factors and yield changes. Relationships between crop or fruit productivity and low temperature indices can provide basic information on the frequency and magnitude of extremes events and their influence on agricultural or forests, but for timely monitoring or warning, pre- and during- frost damage are of more importance because the occurrence of agro-/forest frost events are always attributed to certain extreme cold processes. So, evaluating the extent of the process event-damage is of more importance. Apricot (Prunus armeniaca L.), the naturally dominant fresh apricot tree species of the warm temperate zone in China, has suffered late spring frost on the flowers and unripe fruits in orchards, which can dramatically impact apricot production (Ozkan, et al., 2018), since it negatively affects the biomass, reproduction, fruit growth, and ultimately the yield and fruit quality. In this paper, a process-based apricot frost model is proposed that could provide timely, accurate monitoring and warning of an apricot frost event based on mereological method throughout the flowering season (from midMarch to late-April), when spring cold occurs in late spring. The main goal is to statistically characterize apricot frost events in the China warm temperate zone and to develop a process-based indicator for timely monitoring and warning of apricot frost 
disaster, with the ultimate goal of facilitating better orchard management to mitigate the effect of disaster weather.

\section{Materials and methods}

\subsection{Study area}

The warm temperate zone of China is a major fresh apricot production area located in Northern China between $24^{\circ} \sim 42^{\circ} \mathrm{N}$ and $125^{\circ} \sim 104^{\circ} \mathrm{E}$ that includes Hebei, Henan, Shandong, Shanxi, Shaanxi, Beijing, and Tianjin provinces, as well as the areas of east of Lanzhou (Gansu province), south of Shenyang (Liaoning province), South of Ningxia, and northern part of Anhui and Jiangsu provinces (Fig.1). Fresh apricots account for more than $50 \%$ of the country's total output in this region (Zhang and Zhang, 2003). The unique geographical location makes it vulnerable to the extreme cold surges from eastern Siberia or eastern Mongolia. The cold air goes south via North China, resulting in frost damage in winter and early spring (Ding and Krishnamurti, 1987; Wang, 2018; Ding et al., 2021). Severe cold extremes have been witnessed frequently in this region, resulting in severe damage to the public and the economy in recent decades. For example, during the early spring period in 2018, an extreme cold weather process assaulted the warm temperate zone, with a temperature decrease of more than $14{ }^{\circ} \mathrm{C}$. This resulted in huge areas of crops and fruit trees, including apricot, being destroyed, and it caused an economic loss of more than 2 billion dollars (Beijing Climate Center, 2018).

\subsection{Meteorology and disaster records}


apricot frost samples, facilitating the identification of indicators of apricot frost in the

110 flowering phase in this study. Meteorological data from 150 weather stations were

111 obtained from the National Meteorological Information Centre, China Meteorological

112 Administration (NMIC, CMA), including daily minimum temperature datasets from

1981 to 2018. Apricot frost disaster records can be derived in the China Meteorological

114 Disasters Book (Hebei, Shandong, Henan, Shaanxi, Shanxi, Gansu, Ningxia, Beijing,

115 Tianjin, Jiangsu, Anhui), the Yearbook of Meteorological Disasters in China, forest and

116 fruit disasters surveys, county-based disaster records for the fruit industry, and relevant

117 media reports. Apricot frost disaster records include the time, location, and the

118 destruction of apricot flowers covering the period from 1981 to 2018 , clearly recorded

119 with the freezing injury time and disaster occurrence areas.

\subsection{Theoretical model of process-based apricot frost disaster}

2.3.1 Derivation of apricot frost disaster-causing factors

Frost is mainly induced by the cold weather process, which can be derived from:

(1) radiation frost, that is surface energy continuously radiates to the atmosphere, during

calm winds, clear skies, and a temperature inversion, (2) advection frost, that is cold air advection to a region during moderate-to-high winds, overcast skies, without inversion, and (3) mixed type of both conditions (Wang et al., 2019). The daily minimum temperature, low temperature duration, diurnal temperature range, and accumulated harmful temperature should always be used as disaster-causing factors for the analysis 
of the three types of frost. The intensity and duration of disaster weather determines whether it can trigger plant injury as was discovered by previous studies (Yang et al., 2016). To demonstrate a frost process on apricot, the frost duration days $(D)$ and the accumulated harmful temperature $\left(T_{\text {cum }}\right)$ were chose to demonstrate a process-based apricot frost event (as showed in fig. 2), which can be defined as $f\left(D, T_{\text {cum }}\right)$.

\subsubsection{Derivation of $T_{\text {cum }}$ and $D$}

Relevant frost trigger thresholds, optimum thermal environment, and the resistance abilities of fruit trees vary with the development phases of the species (Álvaro et al., 2020). Flowering or leaf-out of temperate trees can resist to temperatures between $-8{ }^{\circ} \mathrm{C}$ to $-3{ }^{\circ} \mathrm{C}$ in experimental work or laboratory studies (László et al., 2019; Hatice et al., 2019). Low temperatures $\left(-4^{\circ} \mathrm{C}\right)$ were applied at full flowering to select optimum apricot genotypes (Prunus armeniaca L.) with high resistance to cold in the Cappadocia region (Hatice et al., 2019). However, during clear and windless nights, temperatures measured at $2 \mathrm{~m}$ height under the sheltered conditions of a Stevenson screen were established to be 4 to $8^{\circ} \mathrm{C}$ degrees higher than those in plant tissues (Ducrey, 1998). Temperatures below $0{ }^{\circ} \mathrm{C}$, as recorded in a standard weather station, can potentially be used in frost risk analysis on leaves, flowers and young fruits, for the mismatch of temperatures between plant tissues and weather stations (Yann et al., 2018). Commonly, a measured air temperature that is near to $0{ }^{\circ} \mathrm{C}$ is considered as a frost trigger threshold for cultivated trees in spring (Ducrey, 1998; Perraudin and Fellay, 1975). So, $0^{\circ} \mathrm{C}$ was chosen as the temperature potential threshold demonstrated as $T_{t h r}$, and $T_{\text {cum }}$ was used as the ultimately determination to identify an apricot frost. 
$T_{\text {cum }}$ in an apricot frost event was calculated as follows:

$$
T_{\text {cum }}=\sum_{D=1}^{j}\left(T_{\text {min }}-T_{t h r}\right)
$$

Here, $T_{\text {cum }}$ is the accumulated harmful temperature in the apricot frost event; $T_{\min }$ is the daily minimum temperature below $T_{t h r} . T_{t h r}$ is a threshold temperature, that is $0^{\circ} \mathrm{C}$.

$$
D \text { is the consecutive days that } T_{\min }<T_{t h r} \text {. }
$$

\subsection{Historical apricot frost process representation}

To represent historical apricot frost processes in this study, times and locations of historical apricot frost disaster records, as well as the daily minimum temperature data, were firstly integrated, and afterwards, $D$ and $T_{\text {cum }}$ in the apricot frost process were rechecked and calculated according to formula (1). Extreme low temperature processes causing apricot frost were determined after considering the $D$ in a catchment. We took an apricot frost disaster in early April 1993 in Changzhi county (Shanxi province) as an example. Records describe this apricot frost disaster as, “At the beginning of April 1993, frost weather condition caused apricot, peach and pear petals fell off in Changzhi, Shanxi province". Daily $T_{\min }$ data were extracted from the Changzhi Meteorological Station, with $T_{\min }<0^{\circ} \mathrm{C}$ from April $7^{\text {th }}$ to April $11^{\text {th }}$, with $T_{\min }$ were $-1.8,-3.6,-2.2$, -5.7 and $-2.90^{\circ} \mathrm{C}$. A historical apricot frost process dataset was built, including $D$ and $T_{\text {cum }}$, that is $D$ (5days) $-T_{\text {cum }}\left(-16.2^{\circ} \mathrm{C}\right)$.

According to this method, 202 samples were represented. We randomly chose $10 \%$ of disaster samples for frost identification indicator validation, while $90 \%$ of the disaster samples were used for indicator construction. Detailed information of disaster 
samples for apricot frost are shown in Table 1.

\subsection{Identification of indicators for an apricot frost}

Disaster sample sequence distribution fitting, interval estimation, and other methods to acquire the disaster population characteristics and construct agricultural meteorology disaster indicators have been applied and confirmed in the construction of disaster indicators such as agricultural floods (Yang et al., 2016), waterlogging, drought (Wu et al., 2018), and heat damage (Yang et al., 2020). For apricot frost disasters of different duration (in days), the threshold defines, for " $D-T_{\text {cum }}$ " combinations, the amount of $T_{\text {cum }}$ likely to be triggered for the same $D$ for apricot frost processes. In this study, characterises of disaster population can be attached through the probability density functions or cumulative probabilities of $T_{\text {cum }}$ amount in each of the duration datasets. Afterwards, sample coverage rates (SCR) were calculated for different $D$ to identify the most suitable indicators, considering the distribution of disaster samples in the disaster population probabilities.

\subsubsection{Distribution fitting test of $T_{\text {cum }}$ sets}

Normal, exponential, and uniform distributions are commonly adopted in the expression of disaster characteristics, because of the succinct parameters and simple algorithm. So, we chose the three discrete probability distributions of $T_{\text {cum }}$ amount in different $D$ datasets as candidate distributions, representing the historical apricot frost processes.

Kolmogorov-Smirnov (K-S) was applied for the goodness of fit testing of $T_{\text {cum }}$. 
Kolmogorov-Smirnov (K-S) is a test method for comparing a frequency distribution and a theoretical distribution, or the value distributions of two observations. The null hypotheses of $T_{\text {cum }}$ with a theoretical distribution function in each $D$ were tested with statistical analyses of maximum difference between the empirical and theoretical distribution functions (that is, normal, exponential ${ }_{2}$ and uniform). The null hypothesis is rejected at a given significance level if the test statistic exceeds a critical value (Yang et al., 2016).

$$
D_{n}=\max _{-\infty<x<\infty}|F(x)-\bar{F}(x)|<D_{n, a}
$$

Here, $D_{n}$ is a random variable with distribution dependent on $n ; D_{n, a}$ is a critical value at the level of significance.

\subsubsection{Identification of the trigger value of $T_{\text {cum }}$ for different $D$}

The ideal threshold can express most of the disaster population to ensure the accuracy of identification, while reflecting the concentration of independent samples to avoid misjudgement in non-disaster populations. The most suitable trigger value or disaster indicator can be derived from sample coverage rates (SCR). Firstly, inverse function values of the best fitting of $T_{\text {cum }}$ sets were calculated with $5 \%$ step size. Secondly, SCR were calculated under the inverse function values, and we compared and chose the upper limit with the biggest SCR slope.

$$
S C R_{i}=\frac{n_{i}}{N_{i}}
$$

Here, $S C R_{i}$ is the coverage of disaster samples at the $D$-th duration days; $n_{i}$ is the number of historical disaster samples whose $T_{\text {cum }}$ reaches the cumulative probability of the overall disaster population with $5 \%$ step size; $N_{i}$ is the total 
historical disaster sample at the $D$-th duration days.

217

\subsection{Validation of process-based apricot frost indicator}

\subsubsection{Reserve independent sample test}

The rationality of the threshold for apricot frost was verified by comparing the disaster occurrence consistency between the indicator-based results and historical documentation, using the reserved independent apricot frost samples, as showed in part 2.4 and Table 1.

\subsubsection{Typical process tracking}

An extreme snowfall process and strong wind cooling weather occurred in Northern Hebei in 2018, as a result of which there was frost damage to apricot trees in the northern area. The frost process of apricot in flowering is tracked in this research, through the occurring points and intensity demonstrated in $D$ and $T_{\text {cum }}$, based on the indicators constructed above.

\section{Results}

\section{$3.1 \mathrm{f}\left(D, T_{\text {cum }}\right)$ characteristics in the historical apricot frost}

The percentage of duration days for apricot frost process $(D)$ was calculated based on the disaster samples. As shown in Fig.3, the minimum value of $D$ is 1 , while the maximum is 6 days in the warm temperate zone of apricot in China. A 3-day process was detected as having the highest possibility of apricot frost, followed by 4-day process, with 23.60 and $23.03 \%$ of the frost process continued for 3 days and 4 days, 
respectively. $7.61 \%$ and $6.52 \%$ apricot frost samples lasted for 5 and 6 days, respectively. Considering the frost weather condition and the phenological characteristics that the flowering period of apricot trees generally lasts 7-20 days, 5and 6-day frost processes will be discussed in a unified manner for the convenience of application. Thus, the characteristics of $\left(D, T_{\text {cum }}\right)$ were represented as in Fig.4, and the information of $T_{\text {cum }}$ in 1, 2, 3, 4 and $\geq 5$ days for apricot frost samples are shown in Table 2. The average $T_{\text {cum }} \mathrm{s}$ were $-2.55,-5.53,-11.91,-17.03$ and $-22.81^{\circ} \mathrm{C}$ for $1,2,3$, 4 and $\geq 5$ days processes, respectively.

\subsection{Identification of an apricot frost process}

Results of K-S tests showed that four datasets of $T_{\text {cum }}$ series, that is $D \mathrm{~s} 1,2,4$ and 25, followed normal distribution with K-S Sig: 0.189, 0.438, 0.147 and 0.398, respectively (Table 3). One dataset, that is $T_{\text {cum }}$ series in 2 days, passed the uniform distribution significance test, with K-S Sig. 0.058, while none passed exponential distribution significance. Comparing the 3-candidate distribution fitting, normal distribution showed better performance than uniform or exponential distributions. Mathematical transformation was taken in $T_{c u m}$ in 3-days frost processes, and the final K-S Sig. was 0.078, which passed the significance fitting test.

Normal distribution of $T_{\text {cum }} \mathrm{s}$ at different duration days of apricot frost is shown in Fig.5. The inverse values of normal distribution fitting functions accumulative probability from $70 \%$ to $95 \%$ are shown as Table 4 . The threshold for the apricot frost at each growth stage was identified according to the SCR at 5\% cumulative probability step (Fig.6). Comparing the distribution of SCR in $70 \%$ to $90 \%$, the slope of SCR was 
highest from $75 \%$ to $80 \%$ for 1 to 3 days of apricot frost, while SCR changed gently after $80 \%$, meaning that the disaster samples for 1 to 3 days frost have a high degree of aggregation in range between $75 \%$ to $80 \%$ disaster population cumulative probability. Considering most independent disaster samples are detected in the inverse value range between $75 \%$ and $80 \%$ for 1 - to 3 -days frost processes, and the context of cumulative probability, an inverse value of $80 \%$ cumulative probability is more suitable as a potential threshold, for $80 \%$ of the disaster population can be detected in such $T_{\text {cum }}$ for 1 to 3 days of frost process. Inverse values of $T_{\text {cum }}$ at $80 \%$ normal cumulative probability were firstly calculated as potential thresholds for 1 day, 2 days, and 3 days of frost processes, respectively. For instance, we took the threshold identification of 1day frost: the inverse values of $T_{\text {cum }}$ were $-1.92,-1.74,-1.54,-1.31,-1.02,-0.58{ }^{\circ} \mathrm{C}$ for normal distribution fitting function at 0.7 to 0.95 cumulative probability at $5 \%$ step, meaning that the inverse values can identify $70 \%, 75 \%, 80 \%, 85 \%, 90 \%$, and $95 \%$ of the disaster population for 1-day apricot frost processes. Considering the independent samples distribution and deserter population characteristics, the inverse value of $80 \%$ cumulative probability, that is $-1.54{ }^{\circ} \mathrm{C}$, was identified as the threshold for 1-day frost processes.

\section{Change of SCR for 4 days and $\geq 5$ days of apricot frost processes showed that more} independent disaster samples can be detected with inverse values of higher normal cumulative probability (or lower $T_{\text {cum }}$ ). Looking back at apricot frost processes, we found that frost events can be detected in the preceding three days, meaning that the disaster processes can be timely recognized from the 1-3 days as soon as possible, 
although the process can persist long, and the continuous accumulation of $T_{c u m}$ aggravates the degree of frost damage. For 4 days and $\geq 5$ days of frost processes, the identification thresholds were firstly constructed by the inverse value of $80 \%$ cumulative probability, and then modified according to the results of thresholds of 1to 3-days processes. For instance, we took the threshold identification of 4 days frost: the inverse value of $80 \%$ cumulative probability of $T_{\text {cum }}$ in 4 days of apricot frost processes was $-7.21^{\circ} \mathrm{C}$, which is lower than 4 times of 1 day frost threshold $\left(-1.51^{\circ} \mathrm{C}\right)$, 2 times of 2 days frost threshold $\left(-2.92^{\circ} \mathrm{C}\right)$, and the sum of thresholds for 1 day and 3 days processes $\left(-1.51\right.$ and $\left.-4.39^{\circ} \mathrm{C}\right)$. The minimum value of the above was taken as the threshold for 4 days of frost processes, that is, $-5.84^{\circ} \mathrm{C}$

On that basis, thresholds for the $T_{\text {cum }}$ for apricot frost in 1,2,3,4 and more than 5 days of apricot frost processes were determined, and indicators of apricot frost processes and their activity in disaster samples identification are shown in Table 5. The totally consistent ratio was more than $80 \%$ for disaster samples identification.

\subsection{Validation}

\subsubsection{Validation of reserved independent samples}

Eighteen random historical apricot frost samples were independently selected to validate the applicability of the proposed apricot frost indicators. Table 6 shows the validation results of the reserved independent samples according to the apricot frost indicator constructed previously. All samples of 1-day, 2-days and more than 5-days frost processes can be identified by the indicators, and the coincidence rate of the frost 
indicators-based is $100 \%$. One sample in 3 days and 4 days of apricot frost processes failed in the indicator-based identification, with frost indicator accuracies of $75 \%$ and $80 \%$ for 3-days and 4-days apricot frost processes, respectively. Overall, the results calculated by the frost indicators were generally consistent with disaster records in historical documents, with $89.00 \%$ of indicator-based results completely consistent with historical records, indicating that the apricot frost indicators can reasonably reflect actual apricot frost events in the study area.

\subsubsection{Typical process tracking}

In early spring 2018, a frost event spread from north to south across the warm temperate zone, with a rare snow fall process and strong wind cooling weather. Part of the north region had a minimum temperature below $0{ }^{\circ} \mathrm{C}$ (Zhao et al., 2020). Extremely serious destruction of apricot trees was recorded in North Hebei province (located in the north part of the warm temperate zone) because of the frost event. $T_{\min }$ of April 2018 were extracted from 8 stations in North Hebei, and the average $T_{\min }$ were below $0^{\circ} \mathrm{C}$ from April $3^{\text {th }}$ to $9^{\text {th }}$ (Fig. 7). Based on the indicator constructed previously, apricot frost events according the 8 stations were identified daily in North Hebei, as showed in Fig.8. Two stations, accounting for $25 \%$ stations, detected suffered from apricot frost in $3^{\text {th }}$ April. Apricot frost developed in April $4^{\text {th }}$, with 6 stations identifying apricot frost, and this lasted through April $5^{\text {th }}$ and $6^{\text {th }}$. To April $7^{\mathrm{h}}$, all stations were identified suffer from apricot frost. The frost process alleviated gradually from $8^{\text {th }}$ onward, with $88 \%$ (7 stations) and 38\% (3 stations) detecting apricot frost. 


\subsection{Rationality of theory and method}

The formation of crop frost is governed by the interacting effects of climatic conditions, topography, soil structure, frost tolerance of crop species, and field/orchard management, among which, weather conditions are the most important frost trigger factor for causing a disaster. To investigate regional frost on crop or fruit trees, yield loss and the amount of temperature-related indexes were quantitatively combined, no matter whether the temperature-related indexes are based on meteorological data or remote sensing (Tao et al., 2017; Xiao et al.,2018). Among them, meteorological based methods are recognized as the most convenient monitoring and are uniquely effective early warning tools (Shi et al., 2020). To date, most studies on forest and fruit frost have focused on the analysis of temperature conditions based on various of the apricot tree based on the indicator constructed. agricultural/meteorology index calculations during the growing stages (Yang et al., 2020). Previous indicators of crop frost (such as accumulated frost days or accumulated frost-degree days) (Xiao et al., 2018) could represent frost stress or characteristics in crop planting seasons under climate change, whereas the crop/fruit damage due to frost in each growth stage could be assessed based on the frost indicators, and the unique effects of an apricot frost event on crop damage can be predicted in each growth stage It is accepted that the occurrence of frost can be triggered by a single threshold, what has demonstrated by previous studies on frost (Snyder et al., 2000; Simões et al., 
2015). For example, $285.5 \mathrm{~K}$ was recognized a damage indicator for plants in the tropics (Snyder et al., 2000). However, the extent of crop damage is strongly related to the plant's hardiness and the development of low weather processes. $f\left(D, T_{\text {cum }}\right)$ was adopt to demonstrate process-based apricot frost event, for $D$ is the duration of a frost event and $T_{\text {cum }}$ is the intensity of the frost process. The construction process of apricot frost including $D$ and $T_{\text {cum }}$ is mainly based on the historical disaster representation and re-analysis in stations. The disaster samples cover the spatial region of the study area and confirmed with long series sequence, which is more vital in the representation of $T_{\text {cum }} \mathrm{s}$ in Ds. Statistical analysis, such as the optimal distribution fitting test, probability inverse function, etc., are methods for retracing the occurrence and development processes of the apricot frost in North temperate zone, and the methods of identification of an apricot frost event are both scientific and regionally applicative.

\subsection{Utilization of apricot frost indicators}

The effect of frost on fruit yield and quality is a complex process and is variable, as temperature affects so many biological processes in plants, with different species in different phenological phases each having different responses. Apricot has been recognized as a species that is sensitive to cold weather when flower buds have fulfilled the endodormancy with the beginning of active growth, and flower destruction occurs as a result of frost disaster (Hatice et al., 2019). When the low temperature weather continues and frost stress increases, flowers are injured irreparably with flower shedding, leading to an apricot frost event. The indicators identified in our study demonstrate how low temperature conditions accumulate to frost disaster weather for 
apricot production. The use of the apricot frost indicators can serve as a direct meteorological method to assist in the identification of apricot frost events or processes. Nowadays, operational numerical weather prediction models provide long-term and short-term effective weather forecasts, which help guide the identification of extreme weather phenomena based on space regions and time scales (Susan et al., 2020). The process-based threshold in the identification of apricot frost is operational for its frost forecasting and warning under the given weather forecast productions. More information and measures for apricot frost prevention and mitigation can be implemented according to the indicator-based calculations and results, and these can inform discussions of how to face an apricot frost disaster with the development of weather warning and forecasts.

\subsection{Uncertainties and limitations}

Apricot frost occurrence depends on the climatic conditions, species and stand ages. For example, the relationship between altitude and frost occurrence has been found in experiments (Laughlin, 1982; Laughlin and Kalma, 1987; Susan et al., 2018 and 2020), that daily $T_{\min }$ was lower at higher altitudes in the absence of absorbed ground heat and thinner air. Apricot trees planted in the northward of a hill are likely to experience more harmful cold accumulation than their counterparts southward (Bao, 2011). Eastern slope has been shown to have a higher frequency of frost occurrence than western, for the prolonged cooling hours due to early sunset on the eastern slopes and late sunset on the western slopes lead to heat retention on the ground, which is released at night (Susan et al., 2018). In addition, the degree of cold environment 
exposure in the context of climate change affects apricots' ability to resist frost. Plants frequently exposed to cold conditions may have evolved a greater capacity to conduct a life in such circumstance or to adapt to frost stress (Hatice et al., 2019). For example, frost stress has increased the frost resistance of apricot in Taihang Mountain (including West Shanxi, North Hebei), for meteorological cold weather in such areas has recurred more frequently than in the warm plain in North China. Therefore, it is necessary to continuously optimize and revise the apricot frost trigger thresholds in specific areas according to factors such as soil, terrain, orchard management, and frost resistance abilities. Overall, the apricot frost indicators constructed in this paper is universal in the main apricot-producing areas in the warm temperate zone in China, and they can provide a basis for targeted apricot frost monitoring and warning.

Owing to the complicated interacting effects of external factors, such as weather conditions, water and fertilizer conditions, and orchard management, on perennial fruit trees, it is very difficult to accurately predict loss in quality and yield, that can be attributed solely to frost processes. Additionally, the impact of frost on trees is the result of the interaction between the timing of the event, i.e., full winter vs. active growing season, the low temperature weather processes, and phenological plant status (Marco et al., 2018; Yann et al., 2018; Emilia et al., 2019). Data of apricot phenology, especially the flowering data, is an important factor with regard to frost damage, which is outside of this study's scope. Under global warming, earlier leaf unfolding and flowering for perennial trees has been confirmed by biological observation simulation, as a response to a warmer winter. Obviously the most effective and reliable method to resist late 
409

410

411

412

spring frosts in apricots, thus avoiding frost damage, is late flowering (Hatice et al., 2019). Development of cold weather-resistant species in winter and spring is another strategy to prevent frost damage (Hatice et al., 2019).

\section{Conclusion}

Cold extremes are unavoidable, but the lessons learned from past experience can be used to reduce the damage they inflict. In this study, a process-based apricot frost model $f\left(D, T_{\text {cum }}\right)$ was firstly constructed for the purposes of timely identification of apricot frost events caused by single cold weather processes on the warm temperate zone of China. Characteristics of $T_{\text {cum }}$ were explored under different $\mathrm{D}$ based on the representation of historical apricot frost processes. Thresholds for the $T_{\text {cum }}$ for apricot frost in 1, 2, 3, 4 and more than 5 days lf apricot frost processes were determined as $1.51,-2.92,-4.39,-5.84$ and $-7.31^{\circ} \mathrm{C}$, respectively.

Given the intensification of climate extremes, improving and innovating apricot frost management measures based on such process-based identification indicators is essential to reduce agro-forest losses associated with frost disasters of apricot in the warm temperate zone. Our findings have important implications for government, orchard farmers, and agricultural insurance to take measures for apricot frost prevention and mitigation. With the continuous improvement of yield and quality data and the supplementation of disaster documents, as well as geological, topographical, and orchard managements, apricot frost trigger thresholds will be continuously optimized and revised in specific areas. Additionally, threshold-based classification of disaster evaluation level needs to be elaborated and enhanced, thereby creating a complete 
assessment of apricot frost risk in the main planting area of the warm temperate zone.

\section{Acknowledgements}

We gratefully acknowledge the anonymous reviewers for their valuable comments on the manuscript.

\section{Conflict of interest}

The authors declare that they have no conflict of interests.

\section{Funding Statement}

This work is financially supported by National Key R\&D Program of China (2018YFC1505605, 2017YFC1502801), and the Basic Research Funds-regular at the Chinese Academy of Meteorological Sciences (2020Z005).

\section{Author information}

Affiliations

1. State Key Laboratory of Severe Weather (LASW), Chinese Academy of Meteorological Sciences, Beijing 100081, China Jianying Yang, Zhiguo Huo, Peijuan Wang, Dingrong Wu, Yuping Ma

2. Collaborative Innovation Center of Forecast and Evaluation of Meteorological, Nanjing University of Information Science \& Technology, Nanjing 210044, China Zhiguo Huo

Contributions 

Zhiguo Huo: Supervision.

Peijuan Wang: Conceptualization. study are available from the corresponding author on reasonable request.

\section{Ethics approval} Not applicable. 
Reference:

Álvaro, R.C., Cristina, G., Jesús, R.C., Ramón, P., Guillermo, G., Gordaliza, J., Julio, C., Fernando, M., Luis, G., 2020. Differential response of oak and beech to late frost damage: an integrated analysis from organ to forest. Agricultural and Forest Meteorology. 108243.

Antonio Gazol, J. Julio Camarero, Michele, C., Martín, L., Edurne, M.C., Xaver, S.M., 2019. Summer drought and spring frost, but not their interaction, constrain European beech and Silver fir growth in their southern distribution limits. Agricultural and Forest Meteorology. 278, 107695.

Augspurger, C.K., 2013. Reconstructing patterns of temperature, phenology, and frost damage over 124 years: spring damage risk is increasing. Ecology. 94, 41-50.

Bao, F. P., 2011. Selected Papers of Fu Baopu. Beijing:Meteorological Press.(In Chinese)

Beijing Climate Center, 2018. Monthly Climate Impact Assessment Report in China. https://cmdp.ncc-cma.net/influ/moni_china.php (accessed 14 March 2020).

Chen, L.J., Xiang, H.Z., Miao, Y., Zhang, L., Guo, Z.F., Zhao, X.H., Lin, J.W., Li, T.L., 2014. An overview of cold resistance in plants. J. Agron. Crop Sci. 200, 237-245.

Crimp, S.J., Zheng, B.Y., Khimashia, N., Gobbett, D.L., Chapman, S., Howden, M., Nicholls, N., 2016. Recent changes in southern Australian frost occurrence: implications for wheat production risk. Crop Pasture Sci. 67, 801-811.

Ding, T., Gao, H., Li, X., 2021. Increasing occurrence of extreme cold surges in North China during the recent global warming slowdown and the possible linkage to the 
extreme pressure rises over Siberia. Atmospheric Research, 248, 105198.

492

493

Ding, Y.H., Krishnamurti, T.N., 1987. Heat budget of the Siberian high and the winter monsoon. Mon. Weather Rev. 115, 2428-2449.

Ducrey, M., 1998. Aspects écophysiologiques de la réponse et de l'adaptation des sapins méditerranéens aux extrêmes climatiques: gelées printanières et sécheresse estivale.

Emilia, A., Luigi, S., Gaspare, C., Giovanni, B., Guido, D.U., Salvatore, F.b., Angelo, R., Sergio, R., Antonio, S., Giulliano, B., 2019. Canopy damage by spring frost in European beech along the Apennines: effect of latitude, altitude and aspect", Remote Sensing of Environment, 225, 431-440.

Frederiks, T.M., Christopher, J.T., Sutherland, M.W., Borrell, A.K., 2015. Postheademergence frost in wheat and barley: defining the problem, assessing the damage, and identifying resistance. J. Exp. Bot. 66, 3487-3498.

Gu, L., Hanson, P.J., Post, W.M., Kaiser, D.P., Yang, B., Nemani, R., Pallardy, S.G., Meyers, T., 2008. The 2007 eastern US spring freeze: increased cold damage in a warming world? AIBS Bull. 58, 253-262.

Hatice, D., Veli, E., Ali, K., Said, E.D., Rabia, A.D., Zahide, K., Cemil, E., Tahir, M., Melike, B., 2019. Spring late frost resistance of selected wild apricot genotypes (Prunus armeniaca L.) from Cappadocia region, Turkey. Scientia Horticulturae. 246, 347-353.

Hatice, D., Veli, E., Ali, K., Said, E.D., Rabia, A. D., Zahide, K., Cemil, E., Tahir, M., M, B., 2019. Spring late frost resistance of selected wild apricot genotypes (Prunus 

353.

László, S., Zsuzsanna, G., Magdolna, T.,2019. Frost hardiness of apple (Malus X domestica) flowers in different phenological phases, Scientia Horticulturae. 253, 309-315.

Laughlin, G.P., 1982. Minimum temperature and lapse rate in complex terrain: influencing factors and prediction. Theor. Appl. Climatol. 30 (1), 141-152.

Laughlin, G.P., Kalma, J.D., 1987. Frost hazard assessment from local weather and terrain data. Gricult. For. Meteorol. 40 (1), 1-16

Marco, B., Sofia, B., Francesco, M., Giorgio, M., 2018. Assessing spring frost effects on beech forests in Central Apennines from remotely-sensed data. Agricultural and Forest Meteorology. 248, 240-250.

Ozkan, K., Cafer, K., Tevhit, G., 2018. An exothermic process involved in the late spring frost injury to flower buds of some apricot cultivars (Prunus armenica L.). Scientia Horticulturae. 241, 322-328.

Perraudin, G., Fellay, D., 1975. Les moyens de lutte. La lutte contre le gel. Revue Suisse de Vitic. Arboric. Hortic. 7, 31-54.

Saeidi, M., Eliasi, P., Abdoly, M., Sasani, S., 2012. Freezing tolerance of wheat cultivars at the early growing season after winter. Afr. J. Biotechnol. 11, 40454052.

Shi, J., Cui, L., Tian, Zhan., 2020. Spatial and temporal distribution and trend in flood and drought disasters in East China. Environmental Research. 185, 109406. 
Shimono, H., 2011. Earlier rice phenology as a result of climate change can increase the risk of cold damage during reproductive growth in northern Japan. Agric. Ecosyst. Environ. 144, 201-207.

Simões, D.S., Fontana, D.C., Vicari, M.B., 2015. Use of LST images from MODIS/AQUA sensor as an indication of frost occurrence in RS. Rev. Bras. Eng. Agrõcola e Ambient. 19 (10), 920-925.

Snyder, R.L., 2000. Principles of Frost Protection. Published 2000. (Accessed 3 January 2017). http://biomet.ucdavis.edu/frostprotection/Principles $\% 20$ of $\% 20$ Frost $\% 20$ Protection/FP005.html.

Susan, M., Kotikot, A.F., Robert, E., Griffin, J.N., Jonathan, L.C., Robinson, M., Absae, S., Emily, A., Ashutosh, L., Daniel, E.I., 2020. Statistical characterization of frost zones: Case of tea freeze damage in the Kenyan highlands. Int J Appl Earth Obs Geoinformation. 84, 101971.

Susan, M., Kotikota, A. F., Robert, E.G., Absae, S., James, N., Robinson, M., Ashutosh, L., Daniel, E. I., 2018. Mapping threats to agriculture in East Africa: Performance of MODIS derived LST for frost identification in Kenya's tea plantations. Int. J. Appl. Earth Obs. Geoinformation. 72 , 131-139.

Tao, F.L., Xiao, D.P., Zhang, S., Zhang, Z., Rotter, R.P., 2017. Wheat yield benefited from increases in minimum temperature in the Huang-Huai-Hai Plain of China in the past three decades. Agric. For. Meteorol. 239, 1-14.

Vitasse, Y., Schneider, L., Rixen, C., Christen, D., Rebetez, M., 2018. Increase in the risk of exposure of forest and fruit trees to spring frosts at higher elevations in 

60-69.

Wang, P. J., Huo, Z.G.,Yang, J.Y., Wu, X., 2019. Indicators of chilling damage for spring maize based on heat index in Northeast China. Journal of Applied Meteorological Science, 30(1):13-24. (Chinese with English abstract)

Wang, H.F., Guo, W., Wang, J.H., Huang, W.J., Gu, X.H., Dong, Y.Y., Xu, X.G., 2013. Exploring the feasibility of winter wheat freeze injury by integrating grey system model with RS and GIS. J. Integr. Agric. 12, 1162-1172.

Wang, Z.B., Chen, J., Tong, W.J., Xu, C.C., Chen, F., 2018. Impacts of climate change and varietal replacement on winter wheat phenology in the North China plain. Int. J. Plant Prod. 12, 251-263.

Wang, Z.M., 2018. Tracks and Characteristics Analysis of Strong Cold Air Invading Northern China during Winter Half Year. Doctoral dissertation. Nanjing University of Information Science \& Technology, Nanjing.

Wu, X., Wang, P.J., Huo, Z.G., Wu, D.R., Yang, J.Y., 2018. Crop Drought Identification Index for winter wheat based on evapotranspiration in the HuangHuai-Hai Plain, China. Agric. Ecosyst. Environ. 263, 18-30.

Xiao, L.J., Liu, L.L., Asseng, S., Xia, Y.M., Tang, L., Liu, B., Cao, W.X., Zhu, Y., 2018. Estimating spring frost and its impact on yield across winter wheat in China. Agric.For. Meteorol. 260, 154-164.

Yang, J.Y., Huo, Z.G., Li, X.X., Wang, P.J., Wu, D.R., 2020. Hot weather event-based characteristics of double-early rice heat risk: A study of Jiangxi province, South 
580 Yang, J.Y., Huo, Z.G., Wu, L., Wang, T.Y., Zhang, G.X., 2016. Indicator-based 581 evaluation of spatiotemporal characteristics of rice flood in Southwest China. Agric. Ecosyst. Environ. 230, 221-230.

Yann, V., Léonard, S., Christian, R., Danilo, C., Martine, R., 2018. Increase in the risk of exposure of forest and fruit trees to spring frosts at higher elevations in Switzerland over the last four decades. Agricultural and Forest Meteorology. 248,

Yann, V., Léonard, S., Christian, R., Danilo, C., Martine, R., 2018. Increase in the risk of exposure of forest and fruit trees to spring frosts at higher elevations in Switzerland over the last four decades. Agricultural and Forest Meteorology. 248, $60-69$

Zhang, J.Y., Zhang, Z., 2003. Chinese Fruit Tree (Apricot). China Forestry Publish: Beijing.

Zhao, L.C., Li, Q. Z., Zhang, Y., Wang, H.Y., Du, X., 2020. Normalized NDVI valley area index (NNVAI)-based framework for quantitative and timely monitoring of winter wheat frost damage on the Huang-Huai-Hai Plain, China. Agriculture, Ecosystems and Environment. 292, 106793. 
Figures
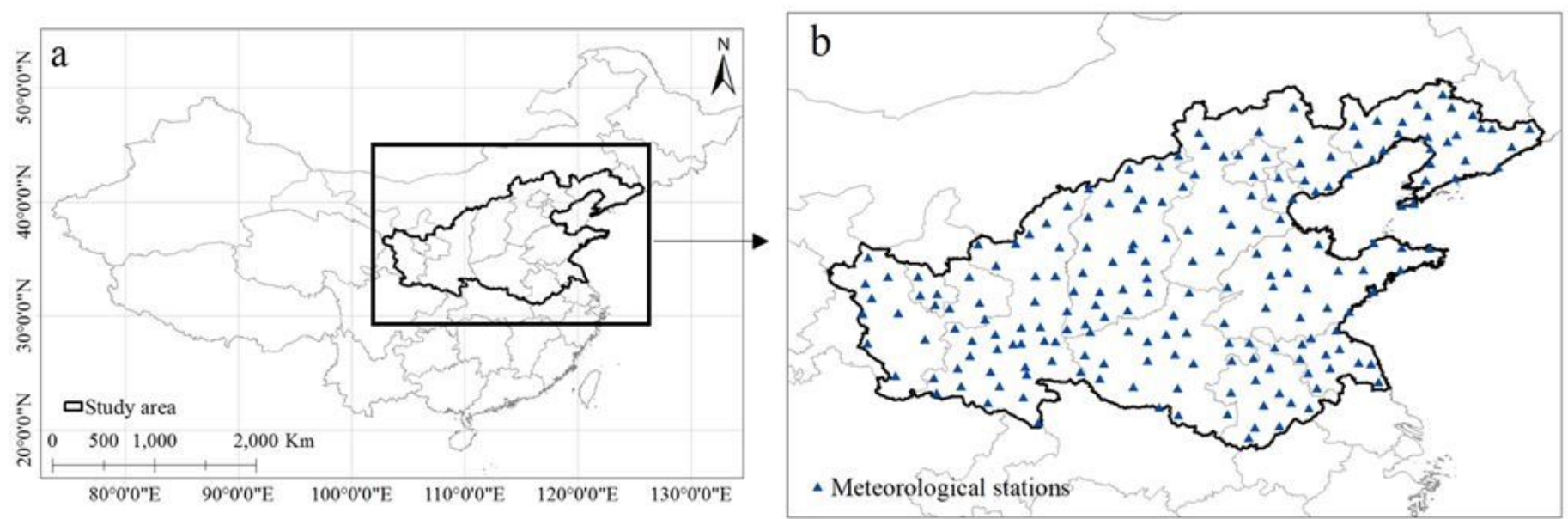

\section{Figure 1}

The inset map shows the location of the warm temperate zone of apricot cultivation and meteorological stations. Note: The designations employed and the presentation of the material on this map do not imply the expression of any opinion whatsoever on the part of Research Square concerning the legal status of any country, territory, city or area or of its authorities, or concerning the delimitation of its frontiers or boundaries. This map has been provided by the authors.

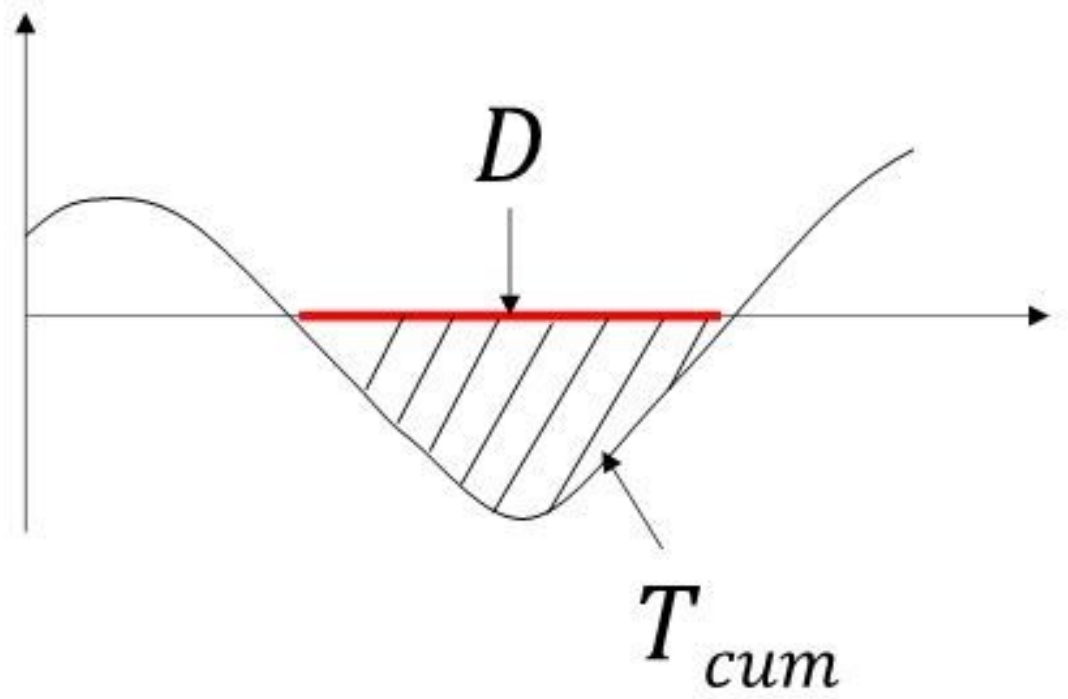

Figure 2 
The theoretical diagram of the apricot frost disaster-causing factors for a process-based apricot frost event.

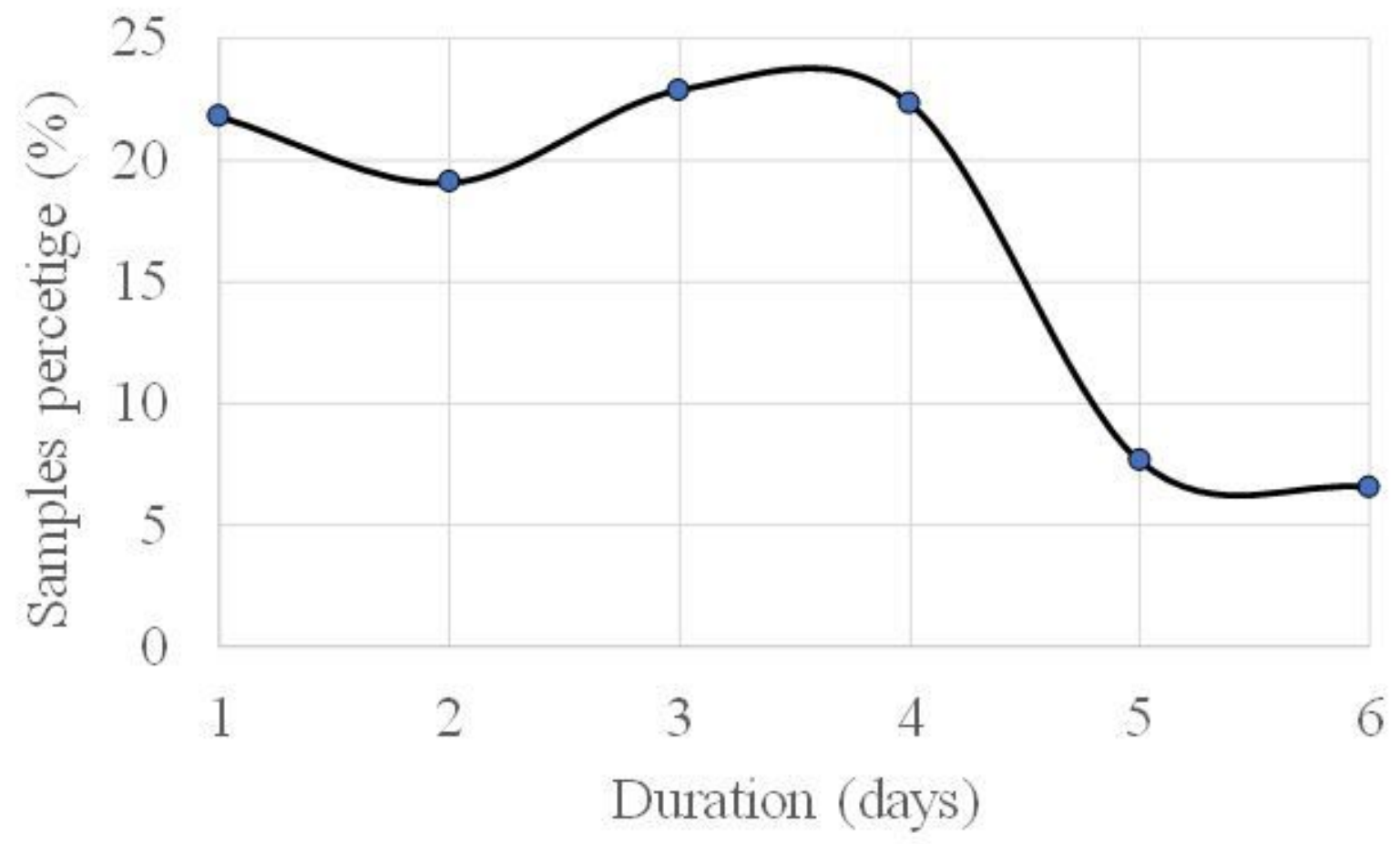

\section{Figure 3}

Duration frequency of $D$ in historical apricot frost samples.

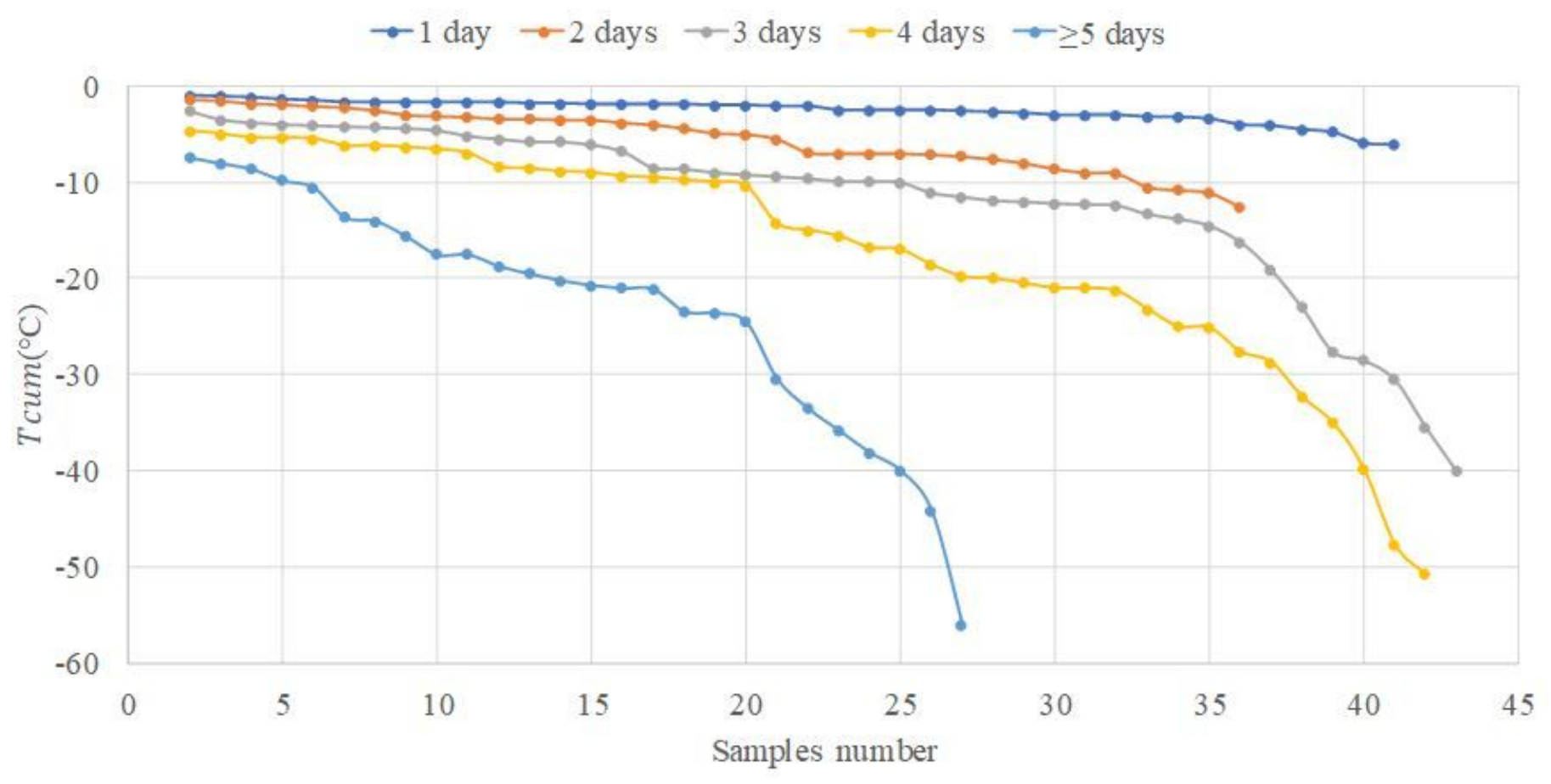


Figure 4

Representation of T_cum characteristics for different D

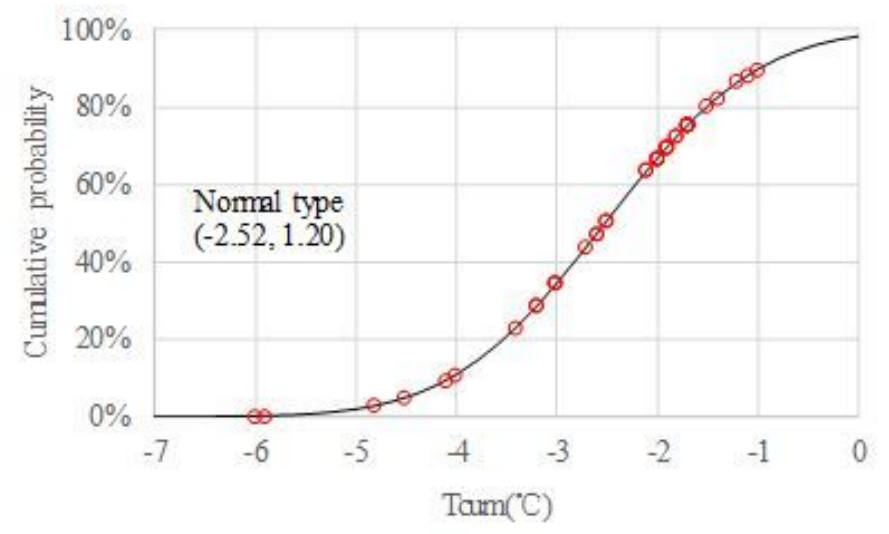

a

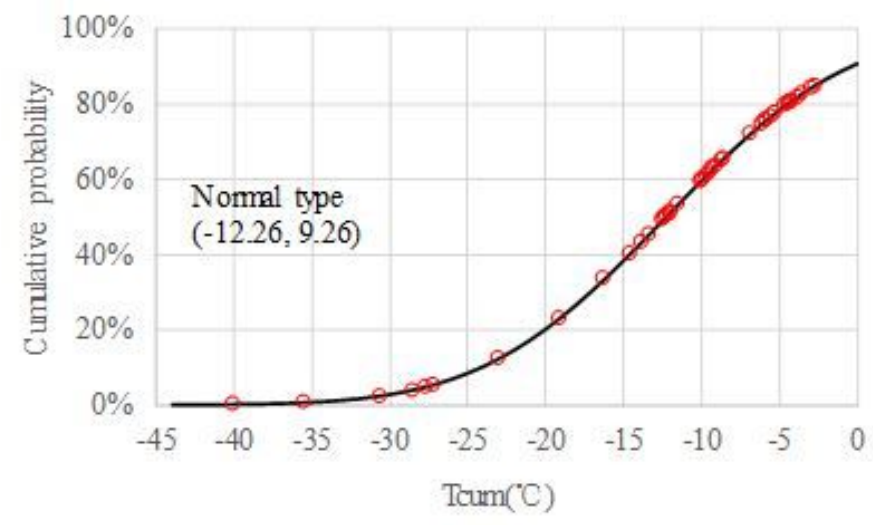

c

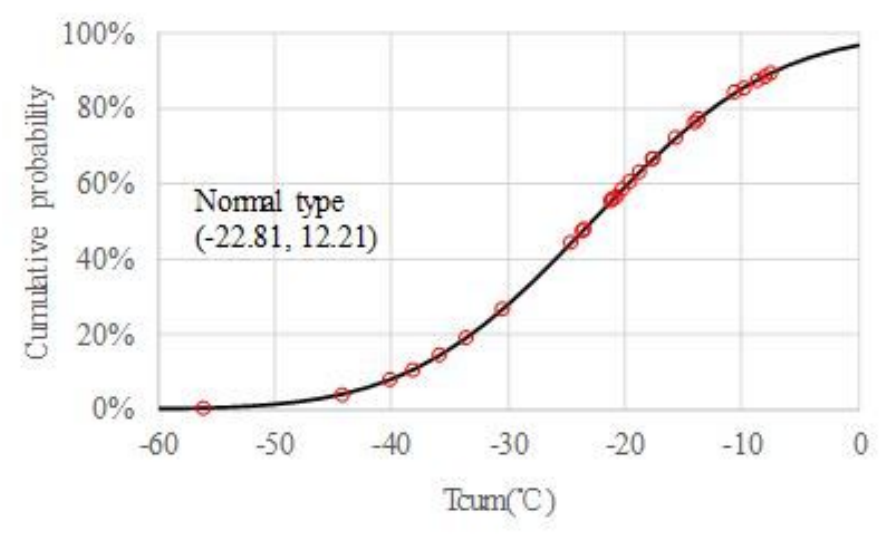

e

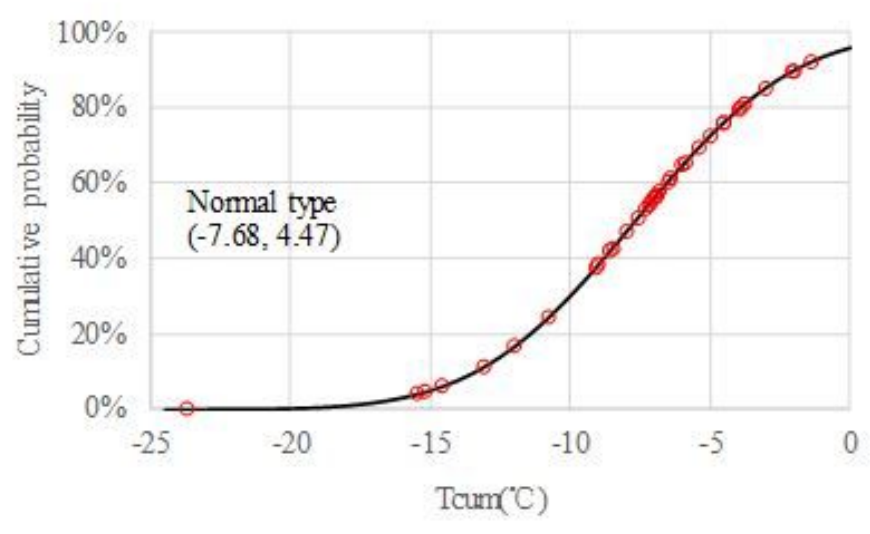

b

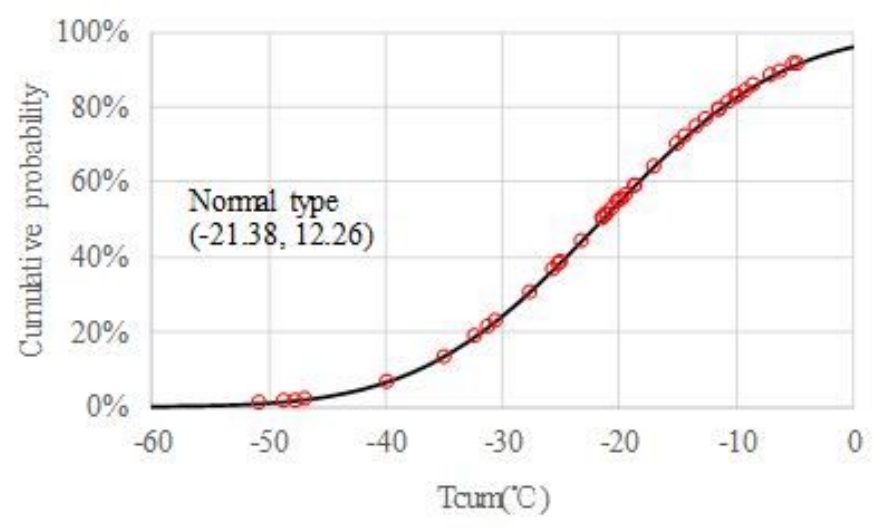

d

\section{Figure 5}

Normal distribution of T_cums for different Ds. Notes: $a$ is normal distribution of T_cums in $D=1$ day; $b$ is normal distribution of $T_{-}$cums in $D=2$ days; $c$ is normal distribution of $T_{-}$cums in $D=3$ days; $d$ is normal distribution of T_cums in $D=4$ days; $e$ is normal distribution of T_cums in $D \geq 5$ days. 


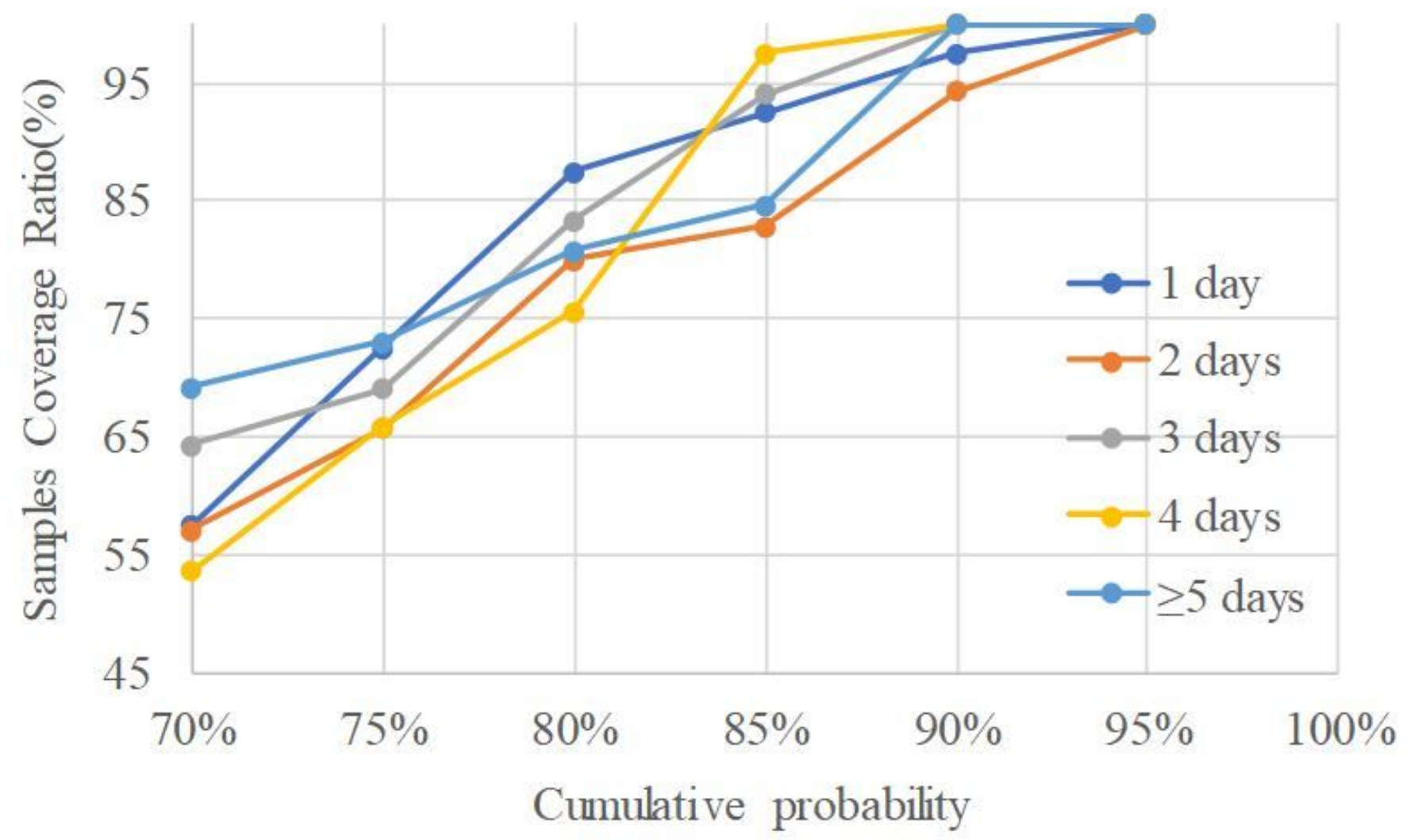

Figure 6

SCR distribution under different cumulative probabilities of best fitting of T_cum

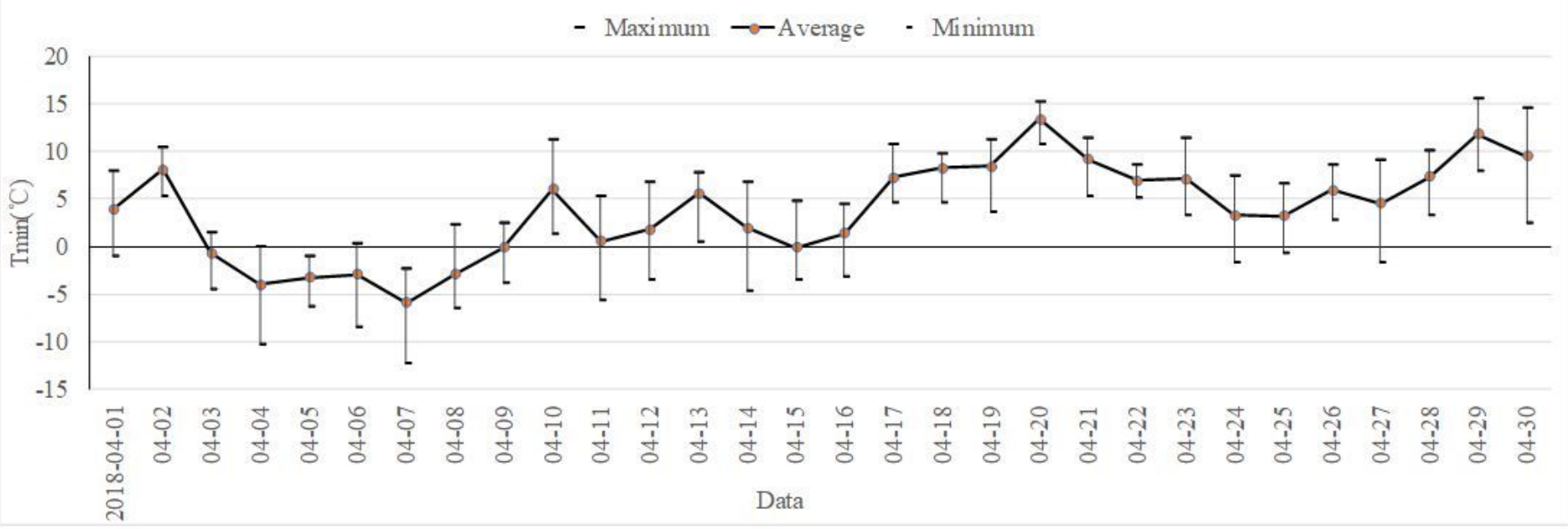

Figure 7

Dairy change of regional T_min in April 2008. 

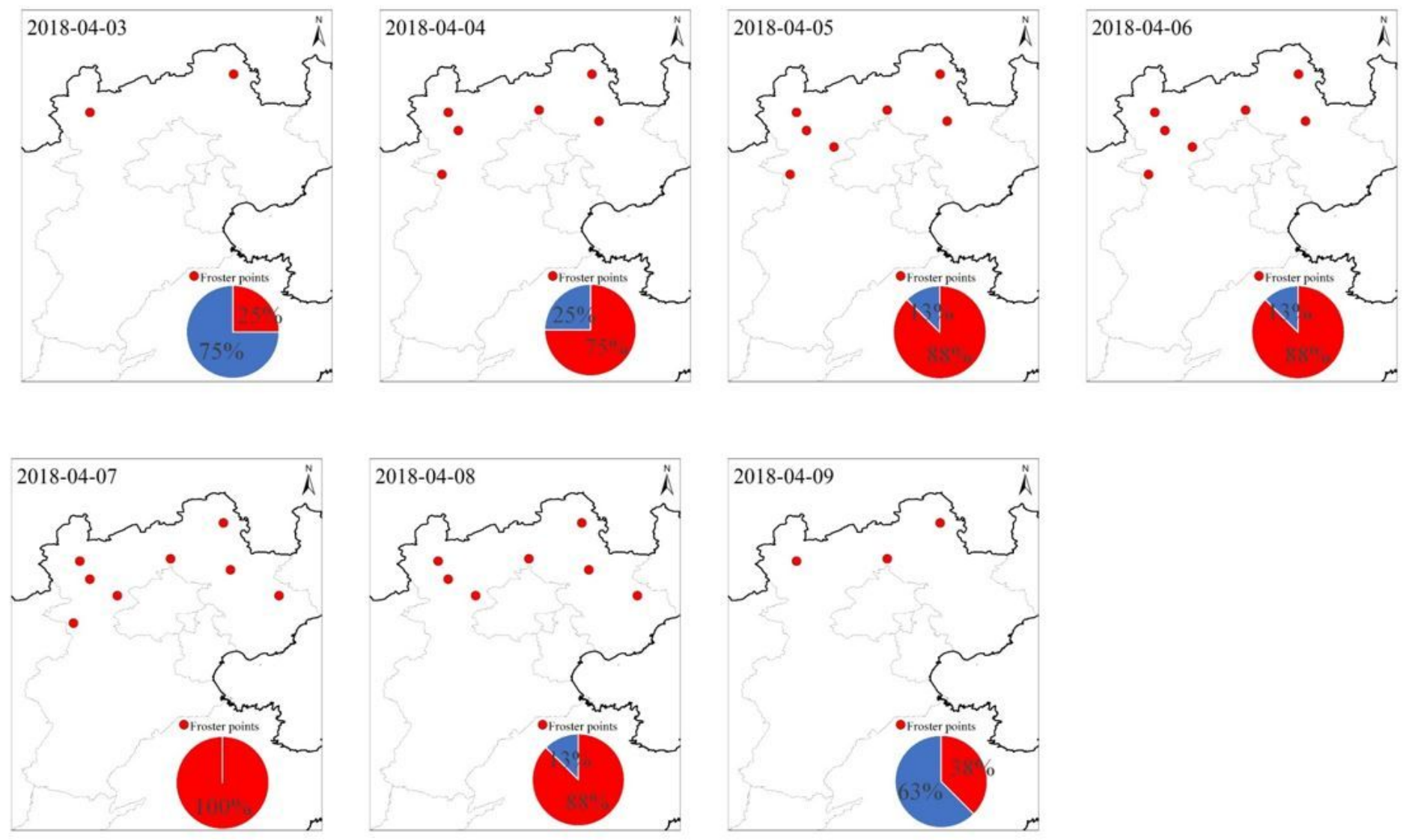

Figure 8

Typical apricot frost process tracking in April 3th-9th, 2008. The red points were identified apricot frost based on the indicator. Note: The designations employed and the presentation of the material on this map do not imply the expression of any opinion whatsoever on the part of Research Square concerning the legal status of any country, territory, city or area or of its authorities, or concerning the delimitation of its frontiers or boundaries. This map has been provided by the authors. 